The differences in the invasiveness of some alien plant species between continental and coastal part of Croatia

Razlike u invazivnosti nekih stranih biljnih vrsta između kontinentalnog i obalnog dijela Hrvatske

Novak, N., Novak, M.

Poljoprivreda/Agriculture

ISSN: $1848-8080$ (Online)

ISSN: 1330-7142 (Print)

http://dx.doi.org/10.18047/poljo.24.2.9

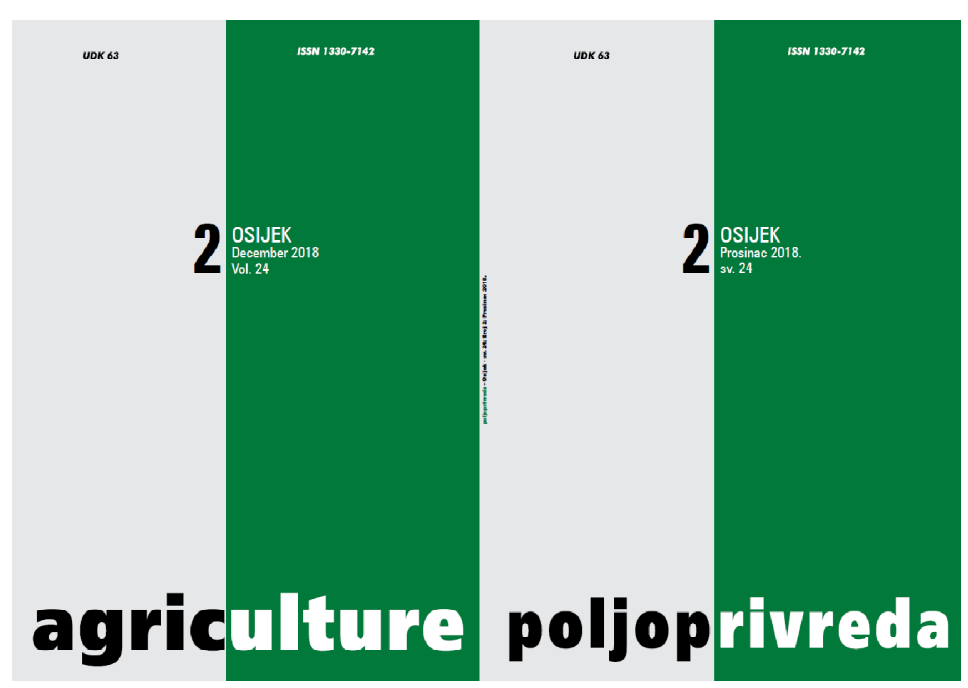

Fakultet agrobiotehničkih znanosti Osijek, Poljoprivredni institut Osijek

Faculty of Agrobiotechnical Sciences Osijek, Agricultural Institute Osijek 


\title{
THE DIFFERENCES IN THE INVASIVENESS OF SOME ALIEN PLANT SPECIES BETWEEN CONTINENTAL AND COASTAL PART OF CROATIA
}

\author{
Novak, N., Novak, M.
}

Professional paper

Stručni članak

\begin{abstract}
SUMMARY
Croatia is a small but heterogeneous country with different pedo-climatic conditions in its parts. In the continental region, mountain region excluded, the climate is moderate continental and in the coastal region Mediterranean and sub-Mediterranean. The aim of this study was to explore the presence, prevalence and level of aggressiveness of some invasive alien plants between continental and coastal part of Croatia. Amorpha fruticosa L., Reynoutria japonica Houtt. and Solidago gigantea Ait. are widespread and very aggressive in the continental and rarely present in coastal part of Croatia. Ailanthus altissima (Mill.) Swingle is present in each Croatian county but it shows greater aggressiveness in the coastal region, including islands and some protected areas.
\end{abstract}

Key-words: Croatia, invasive alien plants, invasiveness, islands, protected areas

\section{INTRODUCTION}

Invasive alien (non-native) species are globally marked as the second greatest threat to biodiversity (Council of Europe, 2007). Invasive alien plants are intentionally or unintentionally introduced into areas outside their natural range. In new areas they show rapid adaptation to new environmental conditions and exceptional ability for rapid reproduction, resulting in their high number and density (Weber, 2005; Novak and Novak, 2017). It is clear that environmental conditions play a crucial role in their successful adaptation.

According to EPPO Climatic Zones the Republic of Croatia is located among Maritime, South-East and Mediterranean part of Europe (EPPO Bulletin, 2014). It is a small but heterogeneous country with different pedo-climatic conditions in its parts. In the Croatian inland climate there is moderately hot humid with warm summers while at higher altitudes climate moderately hot humid with warm summers and wet boreal climate. In the coastal region climate is Mediterranean with hot summer and Mediterranean with warm summer (Šegota and Filipčić, 2003). According to Husnjak et al. (2009) in the area of Panonic lowland (continental part of Croatia) the type of soil is Endogleyic, Luvic Stagnosol (Albic, Epidystric,
Endoeutric, Episiltic, Endoclayic, Ruptic), in the area of mountain region of Gorski kotar the type of soil is Entic Podzol (Endoskeletic) and in the Mediterranean coastal region it is Endostagnic Anthrosol (Eutric, Clayic).

The authors classified those soils according to WRB Classification. Therefore, there is a large difference in soil composition and percentage of organic matter (up to $3 \%$ ) across Croatia (Rašić et al., 2011). Karst areas represent $48.9 \%$ of the land area of Croatia (Bogunović and Bensa, 2006).

According to many literary sources, tree of heaven (Ailanthus altissima (Mill.) Swingle), indigo bush (Amorpha fruticosa L.), Japanese knotweed (Reynoutria japonica Houtt) and giant goldenrod (Solidago gigantea Ait), e.g. species included in this study, are considered significant invasive species (Kowarik and Säumel, 2007; Kovačić et al., 2008; Idžojtić et al., 2009). All four species are included on Preliminary check-list of invasive alien plant species (IAS) in Croatia (Boršić et al., 2008) and were on the EPPO List of invasive alien plants at the time this research was conducted. Preliminary check-

Ph. D. Nenad Novak, Maja Novak, M. Eng. Agr. (maja.novak@hcphs.hr) - Croatian Centre for Agriculture, Food and Rural Affairs - Institute for Plant Protection, Gorice 68b, 10000 Zagreb, Croatia 
list of invasive alien plant species in Croatia consists of 64 species. According to the DAISIE database, two species included in this research, tree of heaven and Japanese knotweed, are classified among the 100 of the world's worst invasive species. Nikolić et al. (2014) consider all four plant species included in this investigation as significant invasive plants in Croatian flora.

Tree of heaven is a deciduous ornamental tree native to China. It was introduced in Europe in the late 1700 s as an ornamental species (Kovačić et al., 2008). Nowadays, the species is spread across all continents except Antarctica, and it is one of the most invasive trees in the world (Kowarik and Säumel, 2007). It can grow rapidly up to $27-30 \mathrm{~m}$ in moderate climatic areas and 18-20 $\mathrm{m}$ in other climatic areas (Kovačić et al., 2008). Idžojtić and Zebec (2006) consider it the most invasive wooden species in Croatia. Indigo bush is a deciduous shrub native to North America. Where native, the species is found in riparian habitats, open rich woods, and in floodplain forests. In places, were invasive, it forms extensive stands due to its dense growth habitat, altering the vegetation structure and replacing native species (Weber, 2005). In Croatia it appeared in the early $20^{\text {th }}$ century (Idžojtić et al., 2009) and was mentioned already in 1938 as a common and dangerous weed in forestry (Liović, 2009). Japanese knotweed is herbaceous perennial ornamental plant native to Japan. The dense foliage and the vegetative growth lead to dense and tall thickets that completely shade out all other vegetation, degrading native plant and wildlife habitats, thus, eliminating native species. Fragments and rhizomes easily resprout and are carried by streams (Weber, 1997). Giant goldenrod is a perennial herbaceous ornamental and bee plant native in North America. Shoot densities may exceed 300 shoots per $\mathrm{m}^{2}$. The species spreads mainly by rhizomes which easily break off and are carried by streams to new sites (Weber, 1997).

The objective of this study was, due to heterogeneous characteristics of the country and well known features of these four invasive alien plants, to investigate differences in their distribution and invasiveness.

\section{MATERIAL AND METHODS}

Monitoring of invasive alien plants was conducted in the period 2007-2014. City of Zagreb and all 20 Croatian counties, including 22 islands (Cres, Lošinj, Krk, Ugljan, Pašman, Dugi otok, Olib, Silba, Premuda, Ist, Murter, Kaprije, Žirje, Prvić, Zlarin, Brač, Čiovo, Hvar, Vis, Mljet, Lopud and Lokrum) and peninsula Pelješac, were covered by the survey. Determining the presence and distribution of invasive alien plants was conducted by expert's visual check two to three times during the growing season (spring and late summer or spring-summer-autumn) in two to three counties annually. The size of infested areas, most common habitat and growing conditions of the species, size and vigour of the populations and the impact on native species were visually evaluated directly on the site by experts included in this investigation. The plant height was measured using the meter. The approximate height of the higher plant that couldn't be measured in this way, was estimated by the expert's assessment. The plant density was measured by numbering the plants on $1 \mathrm{~m}^{2}$ on several sites for each location. The sizes of smaller infested areas were measured using the meter and the sizes of larger infested areas were estimated by the expert's assessment directly on the site. Estimations of larger infested areas were made during the flowering of the species. In some cases, the car distance meter was used where it was possible, depending on the situation in the field. Comparison of invasiveness in continental (excluding mountains) and coastal part of Croatia was made for tree of heaven, indigo bush, Japanese knotweed and giant goldenrod.

\section{RESULTS AND DISCUSSION}

Species included in this study showed a different level of invasiveness in different parts of Croatia.

Tree of Heaven (Ailanthus altissima (Mill.) Swingle)

According to our observations, tree of heaven is present in the whole country (as shown in Table 1). It has been recorded in the City of Zagreb and all 20 Croatian counties. The results are in line with those reported by Idžojtić and Zebec (2006) who consider the tree of heaven the most aggressive invasive tree species in Croatia. It was found out that the species correspond devastated and abandoned habitats such as house ruins, industrial yards, etc., that invades much faster than other species. It is most commonly recorded as a species that is a "companion of man "and is mostly located at the entrances to settlements and in populated places. Tree of heaven is a serious threat to autochthon species and biodiversity, especially in the Mediterranean region of Croatia.

In continental part of Croatia it has expanded in limited areas and does not pose a direct threat. However, in several locations in the eastern Croatia (Vukovar-Srijem County), strong populations with high trees, an abundance of seeds and young shoots were observed. In these areas, tree of heaven forms dense monocultures, suppresses native vegetation and shows a further tendency spread. In some locations in Virovitica-Podravina County, it has exhibited a high degree of aggressiveness in humid habitats along the Drava River.

Due to the high level of resistance to long-lasting droughts and high temperatures, tree of heaven was recorded as a very aggressive species in constant and almost visible expansion in the coastal part of Croatia. Monocultures are larger and denser in coastal part where they often occupy several hectares (as shown in Table 1).

Tree of heaven is also present in some protected areas in Mediterranean region and on many Croatian islands which are especially vulnerable due to their isolated ecosystems. Spreading of tree of heaven was observed on some localities in Krka National Park which 
is also reported in the literature (Novak and Novak, 2017). Its communities were recorded on Kornati National Park, Brijuni National Park, Biokovo Nature Park, Telašćica Nature Park, Vučina Protected area and on 19 from 22 islands inspected. It was not recorded only on three islands - Ist, Lopud and Lokrum. On some islands, locations of findings are related to the human activity and its prevalence is limited. However, on some locations the species completely devastated natural ecosystems.

The conducted monitoring showed that tree of heaven possesses maximum adaptability to the surrounding environment. The obtained results for this species are in line with the results from other studies (Kovačić et al., 2008; Petrova et al., 2013; Novak and Kravarščan, 2014).

Indigo Bush (Amorpha fruticosa L.)

Indigo bush habitats are not so diverse. The results of indigo bush distribution by Croatian counties are presented in Table 1.

On some locations in continental region, it supresses native vegetation and forms dense monocultures. The largest and "the strongest" populations exist on humid habitats where this species is a serious threat to biodiversity. Obtained results are in line with Anastasiu and Negrean (2006) and Blagojević et al. (2015) who also claim that species prefer humid habitats and it is mostly present near irrigation channels and river banks, especially in alluvial or marshy areas. Large areas some of which protected wetland areas in continental region (Lonjsko polje in Sisak-Moslavina County and Kopački rit in Osijek-Baranja County) are seriously infested with monocultures of this species being not in the line with results reported by Sărăţeanu (2010). The author states that indigo bush occurs on poor, degraded, dry and sandy soils.

In the coastal part of Croatia, it is present only sporadically with individual plants (Figure 6 ) or small populations that occupying $10-20 \mathrm{~m}^{2}$ on few locations being in line with Pedashenko et al. (2012). The authors state that cover of indigo bush in Bulgaria is higher on the mainland than on islands. Its invasiveness shows only in the city of Omiš on the banks of the river Cetina in Split-Dalmatia County. On the other parts of Mediterranean region of Croatia it is not a direct threat to native species. This species is not very competitive in long-lasting drought common in coastal part of Croatia.

Table 1. Distribution of Ailanthus altissima ((Mill.) Swingle) and Amorpha fruticosa L. by Croatian counties Tablica 1. Rasprostranjenost vrsta Ailanthus altissima ((Mill.) Swingle) i Amorpha fruticosa L. po hrvatskim županijama

\begin{tabular}{|c|c|c|c|c|c|c|c|c|}
\hline & \multirow{2}{*}{$\begin{array}{l}\text { County } \\
\text { Županija }\end{array}$} & \multirow{2}{*}{$\begin{array}{l}\text { Year of } \\
\text { monitoring } \\
\text { Godina } \\
\text { monitoringa }\end{array}$} & \multicolumn{2}{|c|}{$\begin{array}{l}\text { No. of findings } \\
\text { Broj nalaza }\end{array}$} & \multicolumn{2}{|c|}{$\begin{array}{l}\text { Max. infected area per finding } \\
\left(\mathrm{m}^{2} \text { or ha) }\right. \\
\text { Maks. zaraženo područje po } \\
\text { nalazu ( } \mathrm{m}^{2} \text { or ha) } \\
\end{array}$} & \multicolumn{2}{|c|}{$\begin{array}{l}\text { Max. height }(\mathrm{m}) \text { and density of } \\
\text { plants } \mathrm{m}^{-2} \\
\text { Maks. visina }(\mathrm{m}) \text { i gustoća } \\
\text { biljaka }\left(\mathrm{m}^{-2}\right)\end{array}$} \\
\hline & & & 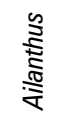 & $\begin{array}{l}\frac{\pi}{2} \\
\frac{2}{2} \\
\frac{1}{4}\end{array}$ & 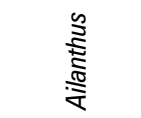 & $\begin{array}{l}\frac{\pi}{5} \\
\frac{5}{2} \\
\frac{1}{4}\end{array}$ & 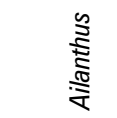 & $\begin{array}{l}\frac{\pi}{5} \\
\frac{2}{2} \\
\frac{1}{4}\end{array}$ \\
\hline \multirow{15}{*}{ 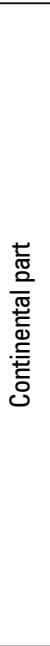 } & City of Zagreb and Zagreb County & 2007 & 67 & - & $5000 \mathrm{~m}^{2}$ & - & $25 / 60$ & - \\
\hline & Varaždin County & 2007 & 12 & - & $1500 \mathrm{~m}^{2}$ & - & $15 / 30$ & - \\
\hline & Koprivnica-Križevci County & 2008 & 9 & 5 & $3000 \mathrm{~m}^{2}$ & 1 ha & $20 / 25$ & $3 / 5$ \\
\hline & Krapina-Zagorje County & 2008 & 6 & 1 & $500 \mathrm{~m}^{2}$ & $100 \mathrm{~m}^{2}$ & $15 / 20$ & - \\
\hline & Međimurje County & 2008 & 7 & - & $5000 \mathrm{~m}^{2}$ & - & $15 / 20$ & - \\
\hline & Bjelovar-Bilogora County & 2009 & 5 & 2 & $1000 \mathrm{~m}^{2}$ & 1 ha & $15 / 20$ & $3 / 5$ \\
\hline & Karlovac County & 2009 & 12 & 5 & $3000 \mathrm{~m}^{2}$ & $\begin{array}{c}\text { several dozen } \\
\text { ha }\end{array}$ & $15 / 20$ & $3 / 7$ \\
\hline & Sisak-Moslavina County & 2010 & 18 & 83 & $3000 \mathrm{~m}^{2}$ & 100 ha & $20 / 30$ & $3 / 10$ \\
\hline & Brod-Posavina County & 2011 & 11 & 75 & $1000 \mathrm{~m}^{2}$ & 100 ha & $15 / 30$ & $3 / 10$ \\
\hline & Požega-Slavonija County & 2011 & 16 & 20 & $1000 \mathrm{~m}^{2}$ & $1000 \mathrm{~m}^{2}$ & $20 / 50$ & $3 / 6$ \\
\hline & Virovitica-Podravina County & 2012 & 11 & 4 & $3000 \mathrm{~m}^{2}$ & $100 \mathrm{~m}^{2}$ & $15 / 40$ & $3 / 10$ \\
\hline & Osijek-Baranja County & 2013 & 12 & 20 & $1000 \mathrm{~m}^{2}$ & 100 ha & $15 / 50$ & $4 / 10$ \\
\hline & Vukovar-Srijem County & 2014 & 20 & 55 & $5000 \mathrm{~m}^{2}$ & 10 ha & $20 / 50$ & $4 / 7$ \\
\hline & Lika-Senj County & 2009 & 1 & - & $100 \mathrm{~m}^{2}$ & - & $10 / 5$ & - \\
\hline & Primorje-Gorski kotar County & 2010 & 1 & - & $100 \mathrm{~m}^{2}$ & - & $10 / 5$ & - \\
\hline \multirow{7}{*}{ 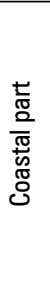 } & Lika-Senj County & 2009 & 48 & - & $5000 \mathrm{~m}^{2}$ & - & $15 / 60$ & - \\
\hline & Primorje-Gorski kotar County & 2010 & 59 & - & several ha & - & $20 / 60$ & - \\
\hline & Istria County & 2010 & 65 & - & several ha & - & $20 / 40$ & - \\
\hline & Zadar County & 2011 & 72 & - & several ha & - & $20 / 60$ & - \\
\hline & Šibenik-Knin County & 2012 & 90 & - & several ha & - & $25 / 60$ & - \\
\hline & Split-Dalmatia County & 2013 & 92 & 8 & several ha & $200 \mathrm{~m}^{2}$ & $25 / 60$ & $3 / 5$ \\
\hline & Dubrovnik-Neretva County & 2014 & 62 & 3 & several ha & $50 \mathrm{~m}^{2}$ & $25 / 60$ & $1,8 / 2$ \\
\hline
\end{tabular}




\section{Japanese Knotweed (Reynoutria japonica Houtt)}

Japanese knotweed is the most common Fallopia species in Croatia, which is in line with Forman and Kesseli (2003) and Bailey et al. (1995) who states that Japanese knotweed is the most common Fallopia species in general. The results of Japanese knotweed distribution by Croatian counties are presented in Table 2.

On many locations in the continental region of Croatia, it suppresses native vegetation and forms dense monocultures. Its habitats are very diverse but usually related to human activity. It is usually found near water courses, traffic roads, in towns, near building sites, industrial yards and other urban areas. Large populations usually exist on humid habitats. Recorded findings are in the line with Beerling, 1991. The largest infested area is the city of Karlovac and the surrounding area with many infested locations and hectares of monocultures of Japanese knotweed. From the Table 2 it is evident that the highest infected area is in Karlovac County. Four rivers which flow through the city of Karlovac make favourable conditions for the invasion of this species. Aguilera et al. (2010) state that Japanese knotweed often forms monocultures being in line with our results.
In the coastal part of Croatia, it is present only sporadically on few locations, mostly as ornamental species and is not considered a threat to biodiversity. Although it was proven to be well tolerant to the salty soil (Richards et al. 2008), the prediction is that it will not become invasive because of dry conditions in Mediterranean part of Croatia.

\section{Giant Goldenrod (Solidago gigantea Ait)}

According to our observations, Solidago gigantea is the most common Solidago species in Croatia. The obtained results are in accordance with those reported by Weber (1998) who states that Solidago gigantea had the highest colonization rate. The results of giant goldenrod distribution by Croatian counties are presented in Table 2 .

In the continental part of Croatia, it has been found on many different ruderal areas usually related to human activity. Infested areas are extremely large and they include thousands of hectares. It is rarely present as an agricultural weed in crops and was recorded only on field margins in maize, being in line with Dajdok and Wuczyński (2008) and Novak and Kravarščan (2011). The highest level of aggressiveness was recorded in abandoned agricultural areas where it often forms dense monocultures and suppresses native species.

Table 2. Distribution of Reynoutria japonica Houtt and Solidago gigantea Ait by Croatian counties

Tablica 2. Rasprostranjenost vrsta Reynoutria japonica Houtt i Solidago gigantea Ait po hrvatskim županijama

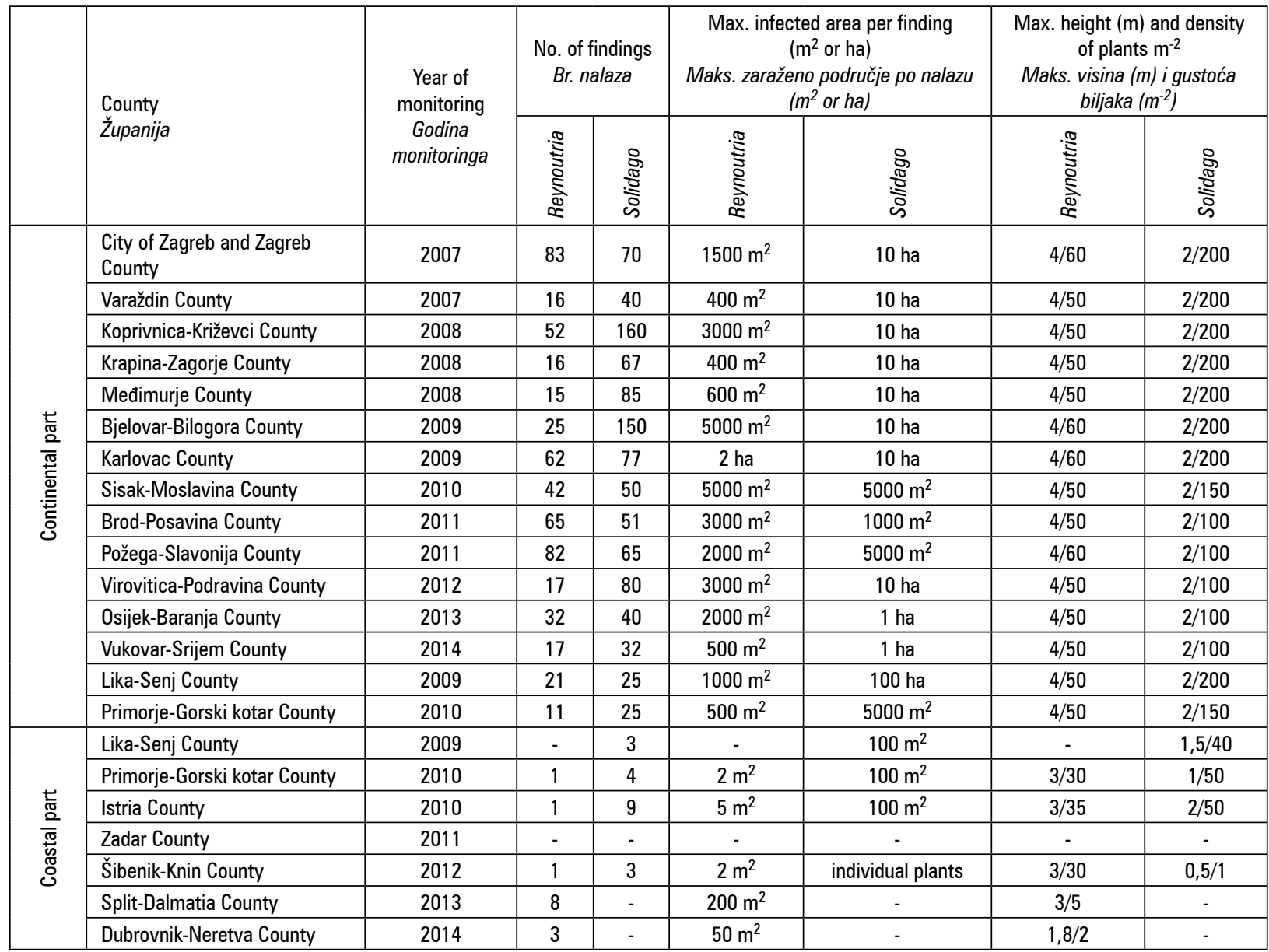


In the coastal part of Croatia, it is only sporadically present, with individual plants or small populations that include several square meters on few locations, but mostly as ornamental species in gardens. Only few individual plants were recorded in Mediterranean part of Croatia e.g. Sibenik-Knin County (as shown in Table 2), so no significant influence on biodiversity in this part of the country is expected. It is evident that this species is not very competitive in Mediterranean pedo-climate conditions.

The obtained results showed that all species included in this study may reduce native species diversity being in line with many authors (Pyšek and Pyšek, 1995; Higgins et al., 1999). Although only a small number of alien species appear to negatively affect native communities (Cronk and Fuller, 2001), it is evident that these species have that feature in some parts of Croatia.

\section{CONCLUSION}

Invasive alien plants colonize many areas of Croatia. Different species behave differently in the continental and coastal part of Croatia. The presence and prevalence of invasive alien plant species are in accordance with pedo-climatic conditions in different parts of Croatia. Indigo bush, Japanese knotweed and giant goldenrod are widespread and very aggressive in the continental and rarely present in Mediterranean region of Croatia. Tree of heaven is present in each Croatian county but it shows greater aggressiveness in the coastal region, including islands and even some protected areas. Human impact is a very important factor in the invasive alien plants spreading. Invasive alien plants can hardly be found in stable ecosystems and untouched environment. Japanese knotweed and Giant Goldenrod are planted and cultivated as ornamental plants. Most of the public is unaware of the danger and potential damages that invasive species can cause. In Croatia, there is no legislation on control and prevention of invasive alien plant species spreading, except ragweed which, despite to the legislation, continues to spread.

\section{REFERENCES}

1. Aguilera, A. G., Alpert, P., Dukes, J. S., \& Harrington, R. (2010). Impacts of the invasive plant Fallopia japonica (Houtt.) on plant communities and ecosystem processes. Biological Invasions 12(5), 1243-1252. https:// doi.org/10.1007/s10530-009-9543-z

2. Anastasiu, P., \& Negrean, G. (2006). Alien vascular plants in Dobrogea (Romania) and their impact on different types of habitats. In D. Ivanova (ed.), Fungal and habitat diversity investigations and observation: conference proceedings of IV Balkan Botanical Congress (590596). Sofia: Institute of Botany, Bulgarian Academy of Sciences.

3. Bailey, J. P., Child, L. E., \& Wade, M. (1995). Assessment of the genetic variation and spread of British populations of Fallopia japonica and its hybrid Fallopia $x$ bohemica. In P. Pyšek, K. Prach, M. Rejmánek \& M. Wade (eds.), Plant invasions: general aspects and special problems: conference proceedings of Plant invasions: general aspects and special problems (141-150). Kostelec nad Černymi lesy: SPB Academic Publishing.

4. Beerling, D. J. (1991). The effect of Riparian land use on the occurrence and abundance of Japanese knotweed Reynoutria japonica on selected rivers in South Wales. Biological Conservation 55(3), 329-337. https:// doi.org/10.1016/0006-3207(91)90036-9

5. Blagojevic, M., Konstantinovic, B., Samardžic, N., Kurjakov, A., \& Orlovic, S. (2015). Seed bank of Amorpha fruticosa L. on some ruderal sites in Serbia. Journal of Agricultural Science and Technology B 5(2), 122-128. https://doi.org/10.17265/2161-6264/2015.02.006

6. Bogunović, M., \& Bensa, A. (2006). Tla krša - temeljni čimbenik biljne proizvodnje. U B. Biondić \& J. Božičević (ur.) Zbornik radova Hrvatski krš i gospodarski razvoj (4150), Gospić: Centar za krš.

7. Boršić, I., Milović, M., Dujmović, I., Bogdanović, S., Cigić, P., Rešetnik, I., Nikolić, T., \& Mitić, B. (2008). Preliminary check-list of invasive alien plant species (IAS) in Croatia. Natura Croatica, 17(2): 55-71. https://www.researchgate.net/publication/27212657_Preliminary_check-list of Invasive_Alien_Plant_Species_IAS_in_Croatia

8. Council of Europe (2007). The Bern Convention (Convention on the conservation of European wildlife and natural habitats, Bern, 1979), No.9. Retrieved from https://www.coe.int/en/web/bern-convention

9. Cronk, O. C. B., \& Fuller, J. L. (2001). Plant invaders: the threat to natural ecosystems. Conservation Ecology 5(2): 3. Retrieved from http://www.consecol.org/vol5/iss2/art3/

10. DAISIE database. Retrieved from http://www.europealiens.org/speciesTheWorst.do

11. Dajdok Z., \& Wuczyński A. (2008). Alien plants in field margins and fields of southwestern Poland. Biodiversity Research Conservation 9 (10), 19-34. Retrieved from http://www.iop.krakow.pl/pobierz-publikacje,598

12. EPPO Bulletin (2014). PP 1/241 (2) Guidance on comparable climates 44(3), 281-283. https://doi.org/10.1111/ epp.12137

13. Forman, J., \& Kesseli, R. V. (2003). Sexual reproduction in the invasive species Fallopia japonica (Polygonaceae). American Journal of Botany 90(4), 586-592. doi: 10.3732/ ajb.90.4.586.

14. Higgins, S. I., Richardson, D. M., Cowling, R. M., \& Trinder-Smith, T. H. (1999). Predicting the landscape distribution of invasive alien plants and their threat to native plant diversity. Conservation Biology 13(2), 303-313. https://doi.org/10.1046/j.1523-1739.1999.013002303.x

15. Husnjak, S., Vrbek, B., Pernar, N., \& Rubiniš, V. (2009). Klasifikacija nekih tipova tla u Hrvatskoj i njihova korelacija s WRB. In M. Pospišil (ed.), Proceedings of $44^{\text {th }}$ Croatian \& $4^{\text {th }}$ International Symposium on Agriculture (14-15). Opatija, University of Zagreb, Faculty of Agriculture. Retrieved from http://sa.agr.hr/pdf/2009/ sa2009_a0109.pdf

16. Idžojtić, M., \& Zebec, M. (2006). Rasprostranjenost pajasena (Ailanthus altissima Mill. Swinge) i širenje invazivnih drvenastih neofita u Hrvatskoj. Glasnik za šumske pokuse, posebno izdanje, 5, 315-323.

17. Idžojtić, M., Poljak, I. Zebec, M., \&Perić, S. (2009). Biološka svojstva, morfološka obilježja i ekološki zahtjevi čivitnjače (Am orpha fruticosa L.). In A P. B. Krpan 
(ed.), Proceedings of Biological-Ecological and Energetic Characteristics of Indigobush (Amorpha fruticosa L.) in Croatia (13-13). Zagreb. Retrieved from https://www. bib.irb.hr/406638

18. Kovačić, S., Nikolić, T., Ruščić, M., Milović, M., Stamenković, V., Mihelj, D., \& Topić, J. (2008). Flora jadranske obale i otoka, 250 najčešćih vrsta. Zagreb: Školska knjiga.

19. Kowarik, I., \& Säumel, I. (2007). Biological flora of Central Europe: Ailanthus altissima (Mill.) Swingle. Perspectives in Plant Ecology, Evolution and Systematics, 8(4), 207237. https://doi.org/10.1016/j.ppees.2007.03.002

20. Liović, B. (2009). Obnova šuma hrasta lužnjaka u uvjetima zakorovljenja čivitnjačom (Amorpha fruticosa L.). In A P. B. Krpan (ed.) Proceedings of Biological-Ecological and Energetic Characteristics of Indigobush (Amorpha fruticosa L.) in Croatia (14-14). Zagreb.

21. Nikolić, T., Mitić, B., \& Boršić I. (2014): Flora Hrvatske: invazivne biljke. Alfa d.d. Zagreb.

22. Novak, N., \& Kravarščan M. (2011): Invazivne strane korovne vrste u Republici Hrvatskoj. Zagreb: Hrvatski centar za poljoprivredu, hranu i selo. Retrieved from https://www.hcphs.hr/files/invazivne-strane-korovnevrste.pdf

23. Novak, N., \& Kravarščan, M. (2014). Tree of heaven (Ailanthus altissima (mill.) Swingle) - invasive alien plant species in Croatia. Glasilo biljne zaštite, 14(3), 254-261. https://hrcak.srce.hr/index.php?show= clanak\&id_clanak jezik $=251224$

24. Novak, N., \& Novak, M. (2017). Invazivne strane korovne vrste kao prijetnja zaštićenim područjima. U D. Marguš (ed.), Zbornik radova Vizija i izazovi upravljanja zaštićenim područjima prirode u Republici Hrvatskoj (833-842). Šibenik, Javna ustanova „Nacionalni park Krka“.

25. Pedashenko, H. P., Apostolova, I. I., \& Vassilev, K. (2012). Amorpha fruticosa invasibility of different habitats in lower Danube. Phytologia Balcanica, 18(3), 285-291. http://www.bio.bas.bg/ phytolbalcan/ PDF/18_3/18_3_04_Pedashenko_\&_al.pdf
26. Petrova, A., Vladimirov, V., \& Georgiev, V. (2013). Invasive alien species of vascular plants in Bulgaria. Institue of Biodiversity and Ecosystem Research, Bulgarian Academy of Sciences. Sofia.

27. Pyšek, P., \& Pyšek, A. (1995). Invasion by Heracleum mantegazzianum in different habitats in the Czech Republic. Journal of Vegetation Science, 6(5), 711-718. https://doi.org/10.2307/3236442

28. Rašić, D., Šeput, M., Halter, J., Andrišić, M., Komesarović, B., \& Cvjetković, S. (2011). Organska tvar i pH u tlima istočne Hrvatske. In M. Pospišil (ed.), Proceedings of $46^{\text {th }}$ Croatian \& $6^{\text {th }}$ International Symposium on Agriculture (13-14). Opatija, University of Zagreb, Faculty of Agriculture. Retrieved from http:// sa.agr.hr/pdf/2011/sa2011_proceedings.pdf

29. Richards, C. L., Walls, R. L., Bailey, J. P., Parameswaran, R., George, T., \& Pigliucci, M. (2008). Plasticity in salt tolerance traits allows for invasion of novel habitat by Japanese knotweed s. I. (Fallopia japonica and F. $\times$ bohemica, Polygonaceae). American Journal of Botany, 95(8), 931-942. https://doi.org/10.3732/ ajb.2007364

30. Sărăţeanu, V. (2010). Assessing the influence of Amorpha Fruticosa L. invasive shrub species on some grassland vegetation types from western Romania. Research Journal of Agricultural Science, 42(1), 536-540.

31. Šegota, T., \& Filiščić, A. (2003). Köppenova podjela klima i hrvatsko nazivlje. Geoadria, 8(1), 17-37. https:// hrcak.srce.hr/9626

32. Weber, E. F. (1997). The alien flora of Europe: a taxonom ic and biogeographic overview. Journal of Vegetation Science 8(4), 565-572. https://doi.org/10.2307/3237208

33. Weber, E. (1998). The dynamics of plant invasions: a case study of three exotic goldenrod species (Solidago L.) in Europe. Journal of Biogeography, 25(1), 147-154. https://doi.org/10.1046/j.1365-2699.1998.251119.x

34. Weber, E. (2005). Invasive Plant Species of the World. Oxon: Geobotanical Institute, Swiss Federal Institute of Technology, CABI Publishing. 


\section{RAZLIKE U INVAZIVNOSTI NEKIH \\ STRANIH BILJNIH VRSTA IZMEĐU KONTINENTALNOG \\ I OBALNOG DIJELA HRVATSKE}

\section{SAŽETAK}

Hrvatska je mala, ali heterogena zemlja, s različitim pedološko-klimatskim uvjetima u svojim dijelovima. U kontinentalnoj regiji, isključujući planinsku regiju, klima je umjerena kontinentalna, mediteranska i submediteranska. Cilj ovog istraživanja bio je istražiti prisutnost i razinu agresivnosti nekih invazivnih stranih biljaka između kontinentalnoga i obalnoga dijela Hrvatske. Amorfa (Amorpha fruticosa L.), Japanski dvornik (Reynoutria japonica Houtt.) i velika zlatnica (Solidago gigantea Ait) široko su rasprostranjene i vrlo agresivne u kontinentalnoj, ali slabo prisutne u obalnome dijelu Hrvatske. Pajasen (Ailanthus altissima (Mill.) Swingle) je prisutan u svim županijama, međutim veću agresivnost pokazuje u obalnome području, uključujući otoke $i$ neka zaštićena područja.

Ključne riječi: Hrvatska, invazivne biljne vrste, invazivnost, otoci, zaštićena područja

(Received on 17 May 2018; accepted on 22 November 2018 - Primljeno 17. svibnja 2018.; prihvaćeno 22. studenoga 2018.) 